\title{
Immunopathology and dexamethasone therapy in a new model for malaria-associated acute respiratory distress syndrome
}

\author{
Philippe E Van den Steen ${ }^{1 *}$, Nathalie Geurts ${ }^{1}$, Katrien Deroost ${ }^{1}$, Ilse Van Aelst ${ }^{1}$, Sebastien Verhenne ${ }^{1}$,
} Hubertine Heremans ${ }^{1}$, Jo Van Damme ${ }^{2}$, Ghislain Opdenakker ${ }^{1}$

From Parasite to Prevention: Advances in the understanding of malaria

Edinburgh, UK. 20-22 October 2010

Malaria infection is often complicated by malaria-associated acute respiratory distress syndrome (MA-ARDS), characterized by pulmonary edema and hemorrhages. No efficient treatments are available for MA-ARDS and its pathogenesis remains poorly understood. To develop a new animal model for MA-ARDS, mice were infected with Plasmodium berghei NK65, and the development of MA-ARDS was characterized by increased lung weight, edema, leukocyte infiltration and hemorrhages (Figure 1). The pulmonary expression of several cytokines and chemokines was increased to a higher level than in mice infected with $P$. chabaudi AS, which does not cause MAARDS. By depletion experiments, $\mathrm{CD}^{+} \mathrm{T}$ lymphocytes were shown to be pathogenic. High doses of dexamethasone blocked MA-ARDS, even when administered after appearance of the complication, and reduced pulmonary leukocyte accumulation.

We developed a novel model of MA-ARDS with many similarities to human MA-ARDS and without cerebral complications. This contrasts with the more classical model with $P$. berghei ANKA, characterized by fulminant cerebral malaria. Hence, infection with $P$. berghei NK65

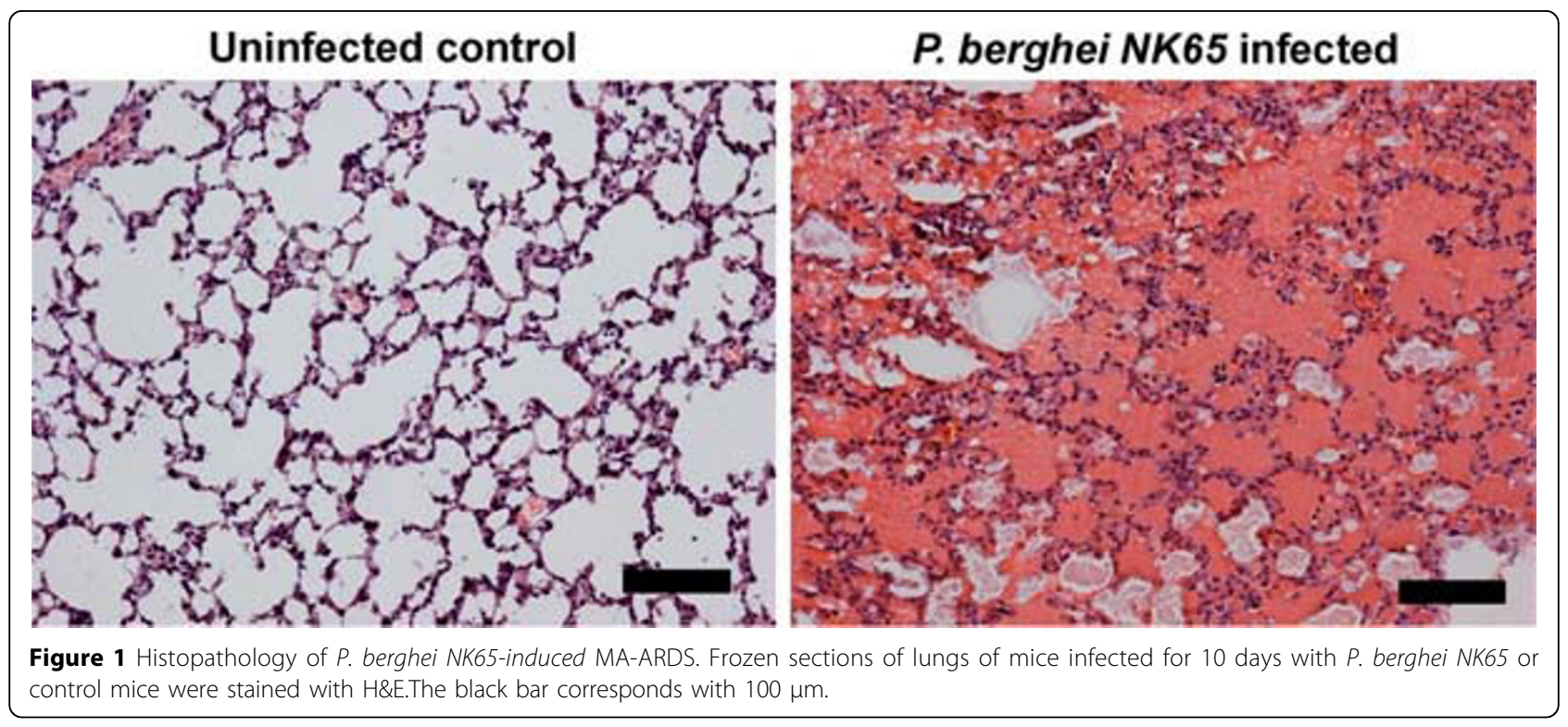

'Laboratory of Immunobiology, Rega Institute, University of Leuven, Belgium

Full list of author information is available at the end of the article 
generates a broader time window to study the pathogenesis and to evaluate candidate treatments. The finding that high doses of dexamethasone cured MA-ARDS suggests that it might be more effective against MA-ARDS than it was in the clinical trials for cerebral malaria.

\section{Author details}

'Laboratory of Immunobiology, Rega Institute, University of Leuven, Belgium. 2Laboratory of Molecular Immunoloby, Rega Institute, University of Leuven, Belgium.

Published: 20 October 2010

\section{Reference}

1. Van den Steen PE, Geurts N, Deroost K, Van Aelst I, Verhenne S,

Heremans H, Van Damme J, Opdenakker G: Immunopathology and dexamethasone therapy in a new model for malaria-associated acute respiratory distress syndrome. Am J Respir Crit Care Med 2010, 181:957-68.

doi:10.1186/1475-2875-9-S2-113

Cite this article as: Van den Steen et al:: Immunopathology and dexamethasone therapy in a new model for malaria-associated acute respiratory distress syndrome. Malaria Journal 2010 9(Suppl 2):113.

\section{Submit your next manuscript to BioMed Central} and take full advantage of:

- Convenient online submission

- Thorough peer review

- No space constraints or color figure charges

- Immediate publication on acceptance

- Inclusion in PubMed, CAS, Scopus and Google Scholar

- Research which is freely available for redistribution

Submit your manuscript at www.biomedcentral.com/submit 